\title{
POLA KEPEMIMPINAN MASYARAKAT ULUAN SUMATERA SELATAN DALAM NOVEL ANAK PERAWAN DI SARANG PENYAMUN KARYA SUTAN TAKDIR ALISJAHBANA \\ (Leadership Patterns of South Sumatera Up-Streamer Uluan in Novel Anak Perawan Di Sarang Penyamun by Sutan Takdir Alisjahbana)
}

\author{
Budi Agung Sudarmanto \\ Balai Bahasa Sumatera Selatan
}

\author{
JL. Seniman Amin Yahya, Jakabaring, Palembang, Sumatera Selatan 30113 \\ Pos-el: budi_agung_s@yahoo.com
}

(Diterima: 27 November 2017; Direvisi: 3 Desember 2017; Disetujui: 29 Desember 2017)

\begin{abstract}
South Sumatera has a very interesting characteristic about up-streamer and down-streamer. One of the descriptions is conveyed in the literary work. The novel of Anak Perawan di Sarang Penyamun by Sutan Takdir Alisjahbana showed a very thick nuance of up-streamer in it. The leadership was in within them. This article aimed at answering the problem of how the leadership in the up-streamer entity in South Sumatera based on the depiction in the literary work of novel Anak Perawan di Sarang Penyamun by Sutan Takdir Alisjhabana was. The stressing of up-streamer was necessary to be done since the locus setting of the novel was in the domain of up-streamer entity. This study applied approach of sociologycal literature. The result was Medasing (being transformed into Pesirah Karim) underwent process to be leader of rogues group, society leader as pesirah, and religion leader (when held title hajj and confirmed as religion affair leader).
\end{abstract}

Keywords: leadership, leader, up-streamer, novel

\begin{abstract}
Abstrak
Sumatera Selatan memiliki karakteristik yang sangat menarik mengenai uluan dan iliran. Salah satu penggambaran tersebut dituangkan di dalam karya sastra. Novel Anak Perawan di Sarang Penyamun karya Sutan Takdir Alisjahbana menunjukkan nuansa uluan yang sangat kental di dalamnya. Kepemimpinan adalah satu di antaranya. Artikel ini bertujuan menjawab permasalahan tentang bagaimanakah pola kepemimpinan entitas uluan yang ada di Sumatera Selatan berdasarkan gambaran dalam karya sastra novel Anak Perawan di Sarang Penyamun karya Sutan Takdir Alisjahbana tersebut. Penekanan tentang uluan perlu dilakukan karena latar tempat kejadian di dalam novel tersebut berada di wilayah entitas uluan (untuk membedakannya dengan iliran) yang ada di Sumatera Selatan. Pendekatan sosiologi sastra diterapkan dalam penelitian ini. Hasilnya adalah Medasing (yang sudah bertransformasi menjadi Pesirah Karim) menjalani proses menjadi pemimpin kelompok penyamun, pemimpin masyarakat sebagai pesirah, dan menjadi pemimpin agama (ketika bergelar haji dan dikukuhkan sebagai pemimpin keagamaan).
\end{abstract}

Kata-kata kunci: kepemimpinan, pemimpin, uluan, novel

\section{PENDAHULUAN}

Karya sastra adalah realita sosial yang bersifat homolog dan simetris (Goldmann dalam Ratna, 2015:126; Faruk, 2015a: 155; Faruk, 2015b:56). Konsep homologi dan simetri membantu memberikan penjelasan bahwa karya sastra memiliki asal-usul yaitu masyarakat itu sendiri. Masyarakatlah yang mengondisikan karya sastra, bukan sebaliknya. Pada gilirannya masyarakat jugalah yang memberikan makna sehingga sebuah karya dapat disebut sebagai memiliki nilai, yang pada gilirannya juga berfungsi untuk menampilkan ciri-ciri masyarakat tertentu.

Karya sastra hadir sebagai hasil dari proses kontemplasi atau perenungan, pengamatan, penghayatan penulis karya sastra, atau sastrawan, terhadap fenomena kehidupan di sekitar mereka. Dalam pandangan Burger dan Luckmann (dalam Ratna, 2011:184) dinyatakan bahwa sebuah 
karya sastra merupakan konstruksi sosial yang totalitas ontologisnya ditentukan oleh keberadaan sosialnya. Sedang menurut pandangan Eagleton (dalam Faruk, 2015b:44) dikatakan karya sastra sebagai cerminan masyarakat. Sementara menurut Swingewood (dalam Faruk, 2015b:47) dikatakan bahwa karya sastra merupakan tiruan terhadap kenyataan yang sebenarnya. Ini artinya karya sastra sangat terkait dengan dunia sosial yang mengelilingi kehidupan sang sastrawan.

Novel Anak Perawan di Sarang Penyamun merupakan satu di antara karya Sutan Takdir Alisjahbana yang berlatar sosial kemasyarakatan Sumatera Selatan. Anak Perawan di Sarang Penyamun berkisah tentang seorang gadis anak seorang saudagar yang dirampok oleh sekelompok penyamun. Latar tempat dari novel ini sekarang berada di wilayah Kabupaten Lahat, Kota Pagaralam, dan Kota Palembang. Dalam kaitan keberadaannya, novel Anak Perawan di Sarang Penyamun karya Sutan Takdir Alisjahbana ini bisa dikategorikan sebagai sebuah karya fiksi serius. Artinya, karya ini memungkinkan pembaca membayangkan sekaligus memahami satu pengalaman manusia. Pengalaman terdiri atas dua lapisan yang melekat satu sama lain. satu bagian tersebut adalah fakta, sedangkan bagian lainnya adalah makna. Bagian makna merupakan bagian yang akan berbeda bagi tiap-tiap orang bergantung pada emosi, standar, dan pemahaman masing-masing atas fakta bersangkutan (Stanton, 2012:6). Dengan membaca karya sastra novel ini pembaca bisa mendapatkan pengalaman yang berupa fakta dan makna tentang sebagian gambaran umum dari sebuah entitas geografis Sumatera Selatan. Karena itulah, karya sastra novel Anak Perawan di Sarang Penyamun ini layak untuk dibicarakan dari banyak sisi.

Orang Sumatera Selatan menyebut wilayah Palembang sebagai wilayah iliran, sedangkan wilayah di luar Palembang disebut wilayah uluan. Dengan demikian, latar tempat dari novel ini yang berada di daerah Lahat dan Pagaralam disebut dengan daerah uluan. Dengan berlatar belakang Sumatera Selatan, karya sastra ini membicarakan tentang kondisi sosial kemasyarakatan yang ada di wilayah Sumatera Selatan. Salah satu hal menarik dan yang menjadi perhatian dalam tulisan ini adalah tentang kepemimpinan yang dibicarakan di dalam novel terutama terkait dengan kepemimpinan di wilayah entitas uluan Sumatera Selatan. Kepemimpinan di iliran dan uluan Sumatera Selatan memiliki perbedaan yang signifikan (Sudarmanto, 2012:112-113). Iliran menganut sistem atau pola kepemimpinan yang turun-temurun, berdasarkan darah (keturunan) keluarga yang genealogis, sedangkan wilayah uluan kepemimpinan didasarkan oleh pemilihan yang dilakukan secara demokratis.

Dikenal beberapa sebutan untuk pemimpin-pemimpin yang ada di uluan. Pasirah mengepalai atau memimpin marga, pembarap mengepalai dusun di mana pasirah berdomisili yang sekaligus pemegang jabatan wakil pasirah jika berhalangan. Sedangkan kepala dusun, secara umum, disebut dengan kerio (Irwanto, 2010:16) atau peroatin (Irwanto, 2010:75).

Penelitian ini bertujuan untuk menjawab permasalahan tentang bagaimanakah pola kepemimpinan entitas uluan yang ada di Sumatera Selatan berdasarkan gambaran dalam karya sastra novel Anak Perawan di Sarang Penyamun karya Sutan Takdir Alisjahbana tersebut. Penekanan tentang uluan perlu dilakukan karena latar tempat kejadian di dalam novel tersebut berada di wilayah entitas uluan (untuk membedakannya dengan iliran) yang ada di Sumatera Selatan.

\section{LANDASAN TEORI}

Kepemimpinan dalam Kamus Bear Bahasa Indonesia Edisi VI berarti perihal pemimpin dan cara memimpin (2008: 1075) Beberapa ahli menyampaikan pendapat mereka menyinggung permasalahan 
kepemimpinan ini, di antaranya adalah Siagian (2015) dan Kartono (2014). Siagian (2015:27) menyebutkan ada lima tipe kepemimpinan yang dewasa ini dikenal luas. Kelima tipe kepemimpinan tersebut adalah (a) tipe yang otokratik; (b) tipe yang paternalistik; (c) tipe yang kharismatik; (d) tipe yang laissez faire; dan (e) tipe yang demokratik. Hampir mirip dengan yang disampaikan oleh Siagian (2015), Kartono (2014:80-81) menyebutkan ada delapan tipe kepemimpinan, yaitu tipe karismatis, paternalitik dan maternalistis, militeristis, otokratis/otoritatif (authoritative, dominator), laisser faire, populis, administratif, demokratis (group developer).

Otokratis berasal dari perkataan otokrat yang terdiri atas autos yang berarti sendiri dan kratos yang berarti kekuasaan atau kekuatan. Jadi otokratis berarti penguasa absolut (Kartono, 2014:83). Pemimpin yang otokratik adalah seseorang yang sangat egois. Seorang pemimpin yang otokratik cenderung menganut nilai organisasional yang berkisar pada pembenaran segala cara yang ditempuh untuk pencapaian tujuannya. Suatu tindakan akan dinilainya benar apabila tindakan itu mempermudah tercapainya tujuan dan semua tindakan yang menjadi penghalang akan dipandangnya sebagai sesuatu yang tidak baik dan dengan demikian akan disingkirkannya, apabila perlu dengan tindakan kekerasan (Siagian, 2015:31). Pemimpin seperti ini berperan sebagai pemain tunggal pada a one-man show. Dia berambisi untuk menguasai situasi. Setiap perintah dan kebijakan ditetapkan tanpa konsultasi dengan bawahannya. Anak buah tidak pernah diberi informasi mendetail mengenai rencana dan tindakan yang harus dilakukan. Semua pujian dan kritik terhadap segenap anak buah diberikan atas pertimbangan pribadi sendiri. Sikap dan prinsip-prinsipnya sangat konservatif atau kuno dan ketat-kaku. Yang paling disukai adalah tipe anak buah yang 'hamba nan setia' (Kartono, 2014:83-84).

Selanjutnya dibahas tentang pemimpin yang paternalistik. Kartono (2014:80) menyebutnya dengan pemimpin paternalistis dan maternalistis. Secara sederhana Kartono menyebut paternalistis dengan pemimpin yang kebapakan (paternalistis) dan keibuan (matermalistis). Menurut Siagian (2015:3336) pemimpin yang paternalistik bersifat tradisional, biasanya ditandai dengan rasa hormat dari para anggota masyarakat kepada seseorang yang dituakan. Pemimpin paternalistik diwarnai oleh harapan pengikut kepadanya yang biasanya berwujud keinginan agar pemimpin mereka mampu berperan sebagai bapak yang bersifat melindungi dan yang layak dijadikan sebagai tempat bertanya dan untuk memperoleh petunjuk. Pemimpin paternalistis menganggap bawahannya sebagai manusia yang belum dewasa atau seperti anak sendiri yang perlu dikembangkan kemampuannya. Selain itu, tipe pemimpin paternalistis bersikap terlalu melindungi (overly protective), jarang memberi kesempatan anak buah untuk mengambil keputusan sendiri dan berinisiatif, serta hampir tidak pernah memberi kesempatan anak buah untuk mengembangkan gagasan dan imajiansinya, karena pemimpin jenis ini merasa maha tahu dan maha benar. Sedangkan penekanan untuk pemimpin maternalistis ditambah dengan over-protective atau terlalu melindungi yang lebih menonjol dan disertai kasih sayang yang berlebihan (Kartono, 2014:81-82).

Pemimpin kharismatik ditandai dengan daya tarik yang kuat dari seorang pemimpin sehingga mampu memperoleh pengikut dalam jumlah yang sangat banyak. Pemimpin kharismatik adalah seseorang yang dikagumi oleh banyak pengikut meskipun para pengikut tidak selalu dapat menjelaskan secara konkret mengapa orang tertentu itu dikagumi (Siagian, 2015:37). Menurut Kartono (2014:81), pemimpin kharismatis memiliki kekuatan energi, daya tarik, dan perbawa yang luar biasa untuk mempengaruhi orang lain, sehingga ia bisa mempunyai pengikut yang sangat besar jumlahnya dan pengawal-pengawal yang bisa 
dipercaya. Sampai sekarang pun orang tidak mengetahui benar sebabnya mengapa seseorang memiliki kharisma yang begitu besar. dia dianggap mempunyai kekuatan gaib (supernatural power) dan kemampuankemampuan yang superhuman. Dia banyak memiliki inspirasi, keberanian, dan berkeyakinan teguh pada pendirian sendiri. Totalitas kepribadian pemimpin seperti ini memancarkan pengaruh dan daya tarik yang teramat besar.

Pemimpin dengan tipe laissez faire adalah semacam pemimpin yang berperan sebagai "polisi lalu lintas", artinya seorang pemimpin seperti ini cenderung memilih peranan yang pasif dan membiarkan organisasi berjalan menurut temponya sendiri tanpa banyak mencampuri bagaimana organisasi harus dijalankan dan digerakkan. Dengan sikap yang permisif, perilaku pemimpin seperti ini cenderung mengarah pada tindak-tanduk yang memperlakukan bawahan sebagai rekan kerja (Siagian, 2015:38-39). Kurang lebih sama pendapatnya dengan Siagian, Kartono (2014:84-85) juga menyatakan bahwa pemimpin laissez faire praktis tidak memimpin. Dia membiarkan kelompoknya dan setiap orang berbuat semau sendiri. Pemimpin tidak berpartisipasi sedikit pun dalam kelompoknya. Semua pekerjaan dan tanggung jawab dilakukan oleh bawahan. Pemimpin seperti ini hanyalah semacam simbol, dan biasanya tidak memiliki keterampilan teknis. Ringkasnya, pemimpin laissez faire pada hakikatnya bukanlah pemimpin dalam pengertian sebenarnya. Hal ini disebabkan bawahan dalam situasi kerja sedemikian rupa sama sekali tidak terpimpin, tidak terkontrol, tanpa disiplin, masingmasing orang bekerja semau sendiri dengan irama dan tempo 'semau gue'.

Tipe yang terakhir adalah demokratik, yang memandang peranannya sebagai koordinator dan integrator dari berbagai unsur dan komponen organisasi sehingga bergerak sebagai suatu totalitas. Pendekatan yang dipakai adalah pendekatan holistik dan integralistik. Dia menyadari bahwa mau tidak mau organisasi harus disusun sedemikian rupa sehingga menggambarkan secara jelas aneka ragam tugas dan kegiatan harus terlaksana demi tercapainya tujuan dan sasaran organisasi. Pemimpin yang demokratik dihormati dan disegani dan bukan ditakuti karena perilakunya dalam kehidupan organisasional. Perilakunya mendorong para bawahannya menumbuhkan dan mengembangkan daya inovasi dan kreativitasnya (Siagian, 2015:40-43).

Kartono (2014:86-87) menyebutkan kepemimpinan demokratis sebagai tipe kepemimpinan yang berorientasi kepada manusia, dan memberikan bimbingan yang efisien kepada para pengikutnya. Terdapat koordinasi pekerjaan pada semua bawahan, dengan penekanan pada rasa tanggung jawab internal (pada diri sendiri) dan kerja sama yang baik. Kekuatan kepemimpinan demokratis tidak terletak pada 'person atau individu pemimpin' tetapi justru terletak pada partisipasi aktif dari setiap warga kelompok. Kepemimpinan demokratis menitikberatkan pada permasalahan aktivitas setiap anggota kelompok, juga para pemimpin lainnya, yang semuanya terlibat aktif dalam penentuan sikap, pembuatan rencana-rencana, pembuatan keputusan penerapan disiplin kerja (yang ditanamkan secara sukarela oleh kelompok-kelompok dalam suasana demokratis), dan pembajaan (asal kata baja) etik kerja.

Sedangkan dua jenis atau tipe pemimpin lain yang disebutkan oleh Kartono adalah populis dan administratif. Populis artinya kepemimpinan yang dapat membangun solidaritas rakyat, yang menekankan masalah kesatuan nasional, nasionalisme, dan sikap yang berhati-hati terhadap terhadap kolonialisme dan penindasan-penghisapan serta penguasaan oleh kekuatan-kekuatan asing (luar negeri). Kepemimpinan populis berpegang teguh pada nilai-nilai masyarakat yang tradisional. Biasanya kurang mempercayai dukungan kekuatan serta bantuan hutang-hutang luar negeri (asing). Kepemimpinan jenis ini 
mengutamakan penghidupan (kembali) nasionalisme (Kartono, 2014:85).

Sedangkan tipe administratif atau eksekutif bermakna kepemimpinan yang mampu menyelenggarakan tugas-tugas administrasi secara efektif. Pemimpin terdiri dari teknokrat dan administraturadministratur yang mampu menggerakkan dinamika modernisasi dan pembangunan. Sistem administrasi dan birokrasi yang efektif dan efisien bisa dibangun untuk memantapkan pembangunan. Dengan kepemimpinan administratif seperti ini diharapkan adanya perkembangan teknis, yaitu teknologi, industri, manajemen modern, dan perkembangan sosial di tengah masyarakat (Kartono, 2014:85).

Di Sumatera Selatan dikenal adanya sebutan iliran dan uluan. Keduanya seperti sekeping mata uang; ketika ada penyebutan ilir(an) maka pasti terdikotomikan dengan ulu(an). Iliran adalah sebutan untuk suatu wilayah di daerah hilir; baik hilir sungai atau daerah perairan lainnya. Iliran adalah sebutan khas masyarakat Sumatera Selatan yang bermakna segala sesuatu yang terkait dengan hilir. Secara kultural daerah iliran adalah daerah yang berada di wilayah Kota Palembang. Di luar Kota Palembang disebut dengan daerah uluan. Konsep iliran hanya ada di wilayah Sumatera Selatan. Konsep yang mirip dengan ini adalah "gunung-laut". Terkait dengan kewilayahan Iliran berpusat di Palembang. Pola kepemimpinan di wilayah iliran, untuk saat ini tidak lagi sama seperti seperti di masa lalu yang menggunakan sistem monarki atau kepemimpinan turun-temurun berdasarkan jalur keturunan. Hal ini disebabkan oleh adanya kerajaan dan/atau kesultanan yang berpusat di Palembang (Irwanto, dkk., 2010:1-10).

Menurut Irwanto, dkk. (2010:75) daerah uluan adalah tanah berpuyang dan beraneka suku. Tanah berpunyang maksudnya adalah tanah yang memiliki nenek moyang. Secara kultural konsepsi uluan adalah semua daerah dan suku di luar
Kota Palembang. Orang Kota Palembang dikenal dengan sebutan iliran. Pada dasarnya, masyarakat di luar Kota Palembang, yang disebut dengan orang uluan itu adalah juga dikenal dengan nama "orang pedalaman" Sumatera Selatan, atau Karesidenan Palembang di masa lalunya. Terkait dengan kepemimpinan, secara kultural kedudukan pemerintahan dalam sistem marga (yang ada di wilayah uluan) adalah adanya Pasirah, proatin atau kerio, pembarap, dan penggawo Irwanto, dkk. (2010:23). Pasirah adalah kepala marga (margahoofden). Proatin atau kerio merupakan kepala dusun (doesoenhofden). Seorang proatin yang dusunnya berada di ibukota marga, maka dia disebut sebagai pembarap. Ada sebutan juga penggawa (penggawo) yang mengurus urusan agama.

\section{METODE PENELITIAN}

Pendekatan sosiologi sastra, yaitu analisis atau pembicaraan terhadap karya sastra dengan mempertimbangkan aspekaspek kemasyarakatan (Ratna, 2011: 24). Terkait dengan pembicaraan mengenai kepemimpinan (terutama di ranah entitas uluan) di dalam makalah ini maka pendekatan sosiologi sastra di dalam kajian ini dihubungkan dengan teori-teori kepemimpinan secara umum maupun kepemimpinan yang lazim terjadi di wilayah uluan Sumatera Selatan. Data diambil dari novel yang berjudul Anak Perawan di Sarang Penyamun karya Sutan Takdir Alisjahbana. Analisis data di dalam makalah ini menggunakan pendekatan atau kritik objektif (objective criticism) yang mendekati karya sastra sebagai sesuatu yang berdiri bebas dari penyair (atau sastrawan), audience, dan dunia yang mengelilinginya. Ia menganalisis karya sastra sebagai seuah objek yang mencukupi dirinya sendiri atau hal yang utuh, atau sebuah dunia dalam dirinya (otonom), yang harus ditimbang atau dianalisis dengan kriteria intrinsik (Pradopo, 2011:27). 


\section{PEMBAHASAN}

\section{Ringkasan Karya}

Adalah Medasing yang menjadi pemimpin suatu kelompok penyamun. Bersama dengan Tusin, Sanip, Amat, dan Sohan mereka menguasai hutan rimba di sepanjang Lahat, Endikat, Pagaralam, dan sekitarnya. Kelompok penyamun ini dibantu oleh Samad, sebagai mata-matanya. Kelompok Medasing sangat kejam dan bengis. Medasing menjadi pemimpin penyamun itu menggantikan ayah angkatnya. Ayah dan ibu kandung Medasing meninggal saat sekelompok penyamun mendatangi sekaligus merampok, dan membumihanguskan kampungnya. Setelah itu, Medasing dibawa oleh pemimpin penyamun bersembunyi ke dalam hutan. Sejak itu Medasing menjadi bagian dari kehidupan kelompok penyamun. Oleh ayah angkatnya Medasing diajari bagaimana cara menyamun. Medasing juga diajak mendalami ilmu hitam, sehingga dia bisa menghilang (atau tidak terlihat oleh orang lain) karena memiliki ilmu halimun. Ketika ayah angkatnya meninggal, Medasing terpilih menjadi kepala penyamun. Pemilihan ini didasarkan oleh keturunan, yaitu Medasing adalah anak dari kepala penyamun sebelumnya selain karena Medasing memiliki kemampuan di atas rata-rata dari anggota lainnya.

Suatu ketika kelompok penyamun merampok keluarga Haji Sahak yang baru saja menjual tiga puluh kerbau. Di malam yang sudah diperkirakan, kelompok ini berhasil menemukan keluarga Haji Sahak dan rombongannya di lembah Endikat. Dalam penyamunan kali ini Medasing dan kawankawan berhasil menggasak seluruh harta Haji Sahak, bahkan Haji Sahak terbunuh dalam kejadian itu. Dua anggota rombongan lainnya juga terbunuh, sedangkan istri Haji Sahak terluka dan pingsan karena dihempaskan oleh Medasing. Anak perawan Haji Sahak, yang bernama Sayu, dibawa paksa sekalian oleh Medasing. Kondisi yang mirip terjadi pada Medasing beberapa tahun lalu tatkala dia dibawa paksa oleh ayah angkatnya. Sohan tewas dalam penyamunan ini, sedangkan Amat terluka sangat parah.

Jadilah sekarang anak perawan Haji Sahak berada di sarang penyamun Medasing. Di sana dia bertemu dengan Samad. Samad berjanji akan membebaskan Sayu dari kelompok Medasing. Awalnya Sayu berharap banyak, tetapi pada akhirnya dia meragukan kesungguhan Samad. Akhirnya Sayu memutuskan untuk tetap tinggal di pondok penyamun sampai waktu yang tidak pasti. Waktu berlalu sampai akhirnya Amat meninggal dunia dan dimakamkan secara sangat sederhana di dekat pondok. Selanjutnya kelompok penyamun ini memutuskan berpindah pondok sebelum melakukan perampokan lagi.

Dalam perampokan kali ini Samad diajak merampok karena kekurangan anggota, setelah Sohan dan Amat meninggal. Setelah perampokan ini Tusin dan Samad tidak muncul kembali. Tusin meninggal dan Samad menghilang. Yang kembali ke pondok hanya Medasing dan Sanip. Nasib mereka berdua tidaklah terlalu baik setelah itu.

Di waktu senggangnya mereka berburu di hutan. Saat berburu rusa, Sanip terkena tombaknya sendiri hingga meninggal dunia sedangkan Medasing terperosok ke dalam jurang hingga patah tangannya.

Kini tinggallah Medasing dan Sayu. Dari sini terjadi interaksi yang lebih baik antara mereka berdua. Dari interaksi itu diputuskan mereka kembali ke Pagaralam, ke kampung Sayu. Atas peran besar Sayu, Medasing bertransformasi menjadi pribadi yang sangat baik. Pada akhirnya Medasing dan Sayu menikah. Medasing menjadi pesirah di daerah Pagaralam. Selain itu, Medasing mengubah namanya menjadi Haji Karim tatkala pulang dari Tanah Suci untuk melaksanakan ibadah haji. Kini, dia selain menjadi pemimpin sosial juga sekaligus menjadi pemimpin agama. 


\section{Pola Kepemimpinan Uluan}

Pembahasan tentang

pola kepemimpinan uluan ini dibagi menjadi tiga, yaitu (a) kepemimpinan penyamun, (b) kepemimpinan sosial kemasyarakatan, dan (c) kepemimpinan agama.

\section{a. Kepemimpinan Penyamun}

Kepemimpinan dibutuhkan di dalam seluruh lapisan kelompok sosial kemasyarakatan di manapun, tidak terkecuali di dalam kelompok penyamun yang digambarkan di dalam karya sastra. Di dalam karya sastra novel yang berjudul Anak Perawan di Sarang Penyamun karya Sutan Takdir Alisjahbana ini, kelompok penyamun dipimpin oleh Medasing. Medasing menjadi pemimpin kelompok penyamun tersebut karena dia adalah anak angkat dari kepala penyamun sebelumnya. Selain itu, Medasing terpilih sebagai pemimpin di dalam kelompok penyamun tersebut karena kemampuannya yang rata-rata berada di atas anggota-anggota yang lain.

"Medasing ialah kepala penyamun berlima itu. Kata orang ia kebal, tahan besi, dan ada padanya ilmu halimun untuk melenyapkan diri (Alisjahbana, 2010:3).”

Medasing memang menjadi anak angkat dari pemimpin kelompok penyamun sebelumnya. Dia diambil dan diikutsertakan secara paksa di dalam kelompok penyamun yang dipimpin oleh ayah angkatnya. Medasing menjadi pemimpin kelompok penyamun menggantikan ayah angkatnya. Dia sama sekali tidak tahu bagaimana kehidupan menjadi manusia di luar lingkungan sebagai penyamun. Dengan kemampuannya, yang juga didukung oleh keberadaan ayah angkatnya yang mantan pemimpin penyamun, menjadikan dia juga menjadi pemimpin yang disegani. Secara teori Medasing merepresentasikan tipe paternalistik yaitu ditandai oleh rasa hormat anggotanya kepada seseorang yang dianggap dituakan (Siagian, 2015:33--36). Medasing dianggap dituakan karena dia adalah anak angkat dari pemimpin penyamun sebelumnya.

\begin{abstract}
"Sejak ayah angkatnya dan seorang teman yang lain mati di dalam perjuangan di kaki pegunungan, Medasing menjadi kepala perampok berlima itu dan menilik pada ilmu yang diperolehnya, seperti yang diceritakannya kepada teman-temannya, dan kekukuhan badannya, telah patutlah ia menjadi kepala jabal-jabalan itu (Alisjahbana, 2010:7). “
\end{abstract}

Medasing juga pantas menjadi pemimpin dari kelompok penyamun karena dia memiliki kemampuan yang lebih dibandingkan dengan anggota-anggota lainnya. Kartono (2014:39) menyatakan bahwa pemimpin adalah pribadi yang memiliki kecakapan khusus, dengan atau tanpa pengangkatan resmi dapat mempengaruhi kelompok yang dipimpinnya, untuk melakukan usaha bersama mengarah pada pencapaian sasaran-sasaran tertentu. Ini juga bagian dari tipe kepemimpinan kharismatik yang ditandai dengan daya tarik yang kuat dari seorang pemimpin sehingga mampu memperoleh pengikut dalam jumlah yang sangat banyak. Pemimpin kharismatik adalah seseorang yang dikagumi oleh banyak pengikut meskipun para pengikut tidak selalu dapat menjelaskan secara konkret mengapa orang tertentu itu dikagumi (Siagian, 2015:37).

"Ketika itulah ia makin lama makin
dihormati kawan-kawannya, karena
badannya teguh, pikirannya tajam dan ia
andai berjuang dan berani, seakan-akan
badan dan nyawanya tiada berharga sedikit
juapun baginya (Alisjahbana, 2010:4)."

Usaha yang dilakukan Medasing untuk menjadi seorang pemimpin, disadari atau tidak, yang dilakukan bersama ayah angkatnya merupakan bentuk ikhtiar yang luar biasa. Terbukti walaupun menjalani bersama tirakat bersama ayah angkatnya tetapi rupanya kemampuannya yang di atas 
rata-ratalah yang bisa membuktikan perbedaan antara dirinya dengan ayah angkatnya. Medasinglah yang lebih layak untuk memiliki kelebihan, maka pantaslah dia menjadi pemimpin di kemudian hari.

"Tetapi apakah dapat dikerjakan mereka berdua?

Maka bermaksudlah mereka pergi menuntut ilmu yang gaib-gaib. Di Dusun Endikat mereka bersua dengan seorang tua yang termashur karena sihirnya. Di sana mereka belajar beberapa bulan dan ketika masaklah perguruan mereka, maka orang tua itu memberi nasihat pergi bertarak ke gunung Dempo. Di sanalah kabarnya konon tempat jin dan iblis yang dapat memberi manusia kesaktian yang luar biasa (Alisjahbana, 2010:5)."

"Medasing masuk kedalam kepundan. Tiba seperdua ia bertemu dengan gua yang terlindung: disanalah ia bertapa (Alisjahbana, 2010:5).

Tujuh hari tujuh malam ia tak meninggalkan tempat itu. Kabarnya konon bermacam hantu, setan, raksasa dan makhluk yang ngeri yang lain, datang menguji keberanian dan keyakinan hatinya. Pada hari yang penghabisan ia dikunjungi oleh seorang peri, yang amat cantik, yang memberinya bermacammacam kesaktian (Alisjahbana, 2010:5).

Bapak angkatnya rupanya sia-sia bertarak itu, sebab ia tak bersua suatu makhluk apapun (Alisjahbana, 2010:5).”

Dari penjelasan di atas setidaknya bisa dilihat dua jenis atau tipe kepemimpinan yang diperankan oleh Medasing. Sebagai pemimpin kelompok penyamun Medasing, setidaknya, telah memimpin kelompok itu dengan dua jenis kepemimpinan. Yang pertama adalah kharismatis dan yang kedua adalah demokratis. Medasing memimpin dengan cara kharismatis artinya dia memiliki kekuatan, energi, dan perbawa yang luar biasa (Kartono, 2014:81). Dengan segala sesuatu atau atribut yang tersemat di dirinya tersebut, Medasing menjadi dianggap layak untuk memimpin kelompok penyamun tersebut.

Medasing melakukan tirakat atau perjalanan spiritual yang mendalam, yang luar biasa, yang orang lain tidak mampu menjalankannya dengan sempurna hingga di akhir, dan mendapatkan sesuatu dari perjalannya tersebut. Bahkan, ayah angkatnya pun tidak mampu menyelesaikan perjalanan spiritual (supranatural) seperti yang dilakukan oleh Medasing.

Mereka berdua, Medasing dan ayah angkatnya, melakukan perjalanan spiritual dengan menyepi di sekitar kaki gunung Dempo untuk melakukan pertapaan. Medasing malah sampai masuk ke dalam kepundan gunung Dempo tersebut. ayah angkat Medasing juga melakukan hal yang kurang lebih sama dengan apa yang dilakukan oleh Medasing. Selama tujuh hari tujuh malam dia berhasil keluar dari pertapaannya dengan selamat meskipun, ternyata, banyak sekali gangguan dan godaan dia alami selama kurun waktu itu. Konon, sebenarnya dia sudah didatangi dan diganggu oleh bermacam hantu, setan, raksasa, dan makhluk ngeri lainnya. Masing-masing makhluk ini datang untuk menguji keberanian dan keyakinan hati Medasing. Di hari penghabisan Medasing dikunjungi oleh seorang peri yang amat cantik yang memberikan berbagai macam kesaktian padanya. Dengan demikian, berhasillah Medasing menjadi satu figur yang lebih bila dibandingkan dengan yang lainnya, termasuk ayah angkatnya sendiri.

Di lain tempat, ayah angkat Medasing tidak berhasil di dalam bertarak. Apa yang dijalaninya hanya menghasilkan kesia-siaan. Dalam pertapaannya, ayah angkat Medasing tidak bertemu dengan makhluk apapun. Ini artinya bahwa dia gagal untuk menjadi seseorang atau figur yang lebih dibandingkan dengan orang yang lainnya.

Medasing memiliki kesaktian. Dia kebal, tahan besi, dan ada padanya ilmu halimun untuk melenyapkan diri. Artinya senjata tajam tidak bisa menembus kulitnya. Juga, apabila dalam kondisi yang terpojok dan memaksa, 
Medasing bisa mempergunakan ilmu halimunnya untuk melenyapkan diri sehingga orang tidak bisa melihat keberadaannya. Karena itulah dia dipilih untuk menjadi pemimpin kelompok penyamun didasarkan oleh kelebihan yang dimilikinya. Dengan kelebihan yang dimilikinya, anak buah dari kelompok penyamun tersebut merasa lebih aman dan terlindungi dari serangan atau gangguan kelompok dari luar lainnya. Selain itu, di dalam melakukan aksi atau kegiatan penyamunannya kelompok ini lebih tenang karena pemimpin mereka dilengkapi dengan kesaktian yang bisa melindungi mereka.

Medasing, di dalam memimpin kelompok penyamun ini, juga didasari oleh demokrasi. Dia tidak memaksakan diri untuk dipilih menjadi pemimpin. Akan tetapi, secara persetujuan anggota kelompok penyamun tersebut memilih Medasing sebagai pemimpin mereka. Dengan cara pemilihan yang demokratis dan Medasing memimpin juga dengan cara yang demokratis menjadikan kelompok ini kuat karena sebenarnya kekuatan kelompok ini adalah pada partisipasi aktif dari setiap anggotanya (Kartono, 2014:86). Masing-masing anggota memiliki rasa saling memiliki yang tinggi.

\section{b. Kepemimpinan Sosial Kemasyarakatan}

Masyarakat uluan Sumatera Selatan mengenal hirarki kepemimpinan mulai dari pesirah, pembarap atau proatin. Pola kepemimpinan ini hanya ada di wilayah uluan. Tidak ditemukan pola kepemimpinan seperti ini di wilayah iliran Sumatera Selatan. Pasirah adalah kepala marga (margahoofden). Proatin atau kerio merupakan kepala dusun (doesoenhofden). Seorang proatin yang dusunnya berada di ibukota marga, maka dia disebut sebagai pembarap (Irwanto, dkk., 2010:23).

Di dalam Anak Perawan di Sarang Penyamun, Medasing yang awalnya menjadi seorang pemimpin dari sebuah kelompok penyamun, pada akhirnya menjadi seorang pesirah dan menjadi lebih dikenal dengan sebutan Pesirah Karim. Tidak ada lagi yang mengenal sosok Medasing. Nasib Medasing memang ditakdirkan untuk menjadi pemimpin. Masa lalu, sekaligus reputasinya sebagai pemimpin kelompok penyamun telah dikubur dalam-dalam tanpa seorangpun yang tahu kecuali Sayu, istrinya.

Pesirah Karim sangat dicintai oleh masyarakatnya. Dia sangat kharismatik di dalam memimpin rakyatnya. Dengan demian rakyat sangat mencintai dirinya sebagai pemimpin. Medasing atau yang sudah berganti nama menjadi Pesirah Karim sangat perhatian kepada rakyatnya.

\begin{abstract}
"Siapakah yang tidak tahu akan pesirah Karim yang ramah-ramah kepada segala orang, baik kaya maupun miskin? Yang telah bertahun-tahun memerintah di Pagar Alam dan sekitarnya, senantiasa memikirkan nasib rakyat yang terserah kepadanya, sebagai seorang bapa yang bersih hati apabila anaknya bersedih hati, dan bersuka cita apabila anaknya bersuka cita (Alisjahbana, 2010:99-100)."
\end{abstract}

Begitu cinta dan sayangnya rakyat kepada pesirah Medasing, ketika pulang dari naik haji dia disambut dengan penuh suka cita dan kecintaan. Bisa dimaklumi bila rakyat sangat merindukan kehadiran pesirahnya kembali bersama mereka mengingat perjalanan naik haji tersebut menghabiskan waktu sampai dua tahun.

"Tiba dihadapan balai dan rumah kecil berhentilah ketiga puluh pedati itu. Anak pedati masing-masing menanggalkan sapinya. Orang yang keluar dari balai bergesa-gesa pergi menuju ke pedati yang ketiga, yang lebih besar, lapang dan indah dari yang lain. Dari dalam pedati itu keluar seorang laki-laki yang besar badannya, memakai jubah putih berenda hitam dan serban berbintik keputih-putihan, diikuti oleh seorang perempuan yang berpakaian haji sampai tertutup mukanya. Itulah pesirah Karim suami isteri (Alisjahbana, 2010:101).”

Sebagai seorang pemimpin yang baik, 
yang sangat mengayomi, melindungi, dan memperhatikan rakyat yang dipimpinnya, pesirah Karim memberikan pelayanannya dengan semaksimal mungkin dan sebaikbaiknya. Dia selalu berusaha untuk menenangkan hati, menentramkan, memberikan sesuatu yang sangat berguna bagi pemohonnya. Dia tidak tega untuk mengecewakan siapapun yang pernah menghadap padanya.

"Tak seorang juapun yang datang kepadanya minta petua dan pertolongan yang kembali dengan hampa tangan. Dalam segala hal akalnya yang panjang dan hatinya yang penyayang dapat mencahari jalan menolong dan membesarkan hati.

Demikianlah ia sangat dicintai anak buahnya hampa hampa (Alisjahbana, 2010:100).”

Tanggung jawab sebagai seorang pemimpin diemban oleh Medasing dengan penuh tanggung jawab. Dia tidak ingin meninggalkan warganya atau anak buahnya dengan sia-sia. Dia juga menginginkan kemakmuran, kesejahteraan, dan kebahagiaan warganya. Untuk itu, dia selalu berusaha untuk menyediakan waktu untuk warganya.

"Maka pada permulaan malam itu ramailah percakapan dalam balai di tengah rimba itu. Pesirah Karim menceritakan pengalaman dan penglihatannya di jalan dan di negeri asing; sering pula pula ia bertanyakan keadaan anak buahnya sepeninggalnya dan senantiasa giranglah ia rupanya, kalau diceritakan kepadanya kemakmuran anak buahnya dalam dua tahun yang silam itu; tentang hasil padi yang baik, tentang perkawinan, kelahiran dan sebagainya (Alisjahbana, 2010: 101)."

Pesirah memiliki bawahan berupa peroatin dan pembarap. Pasirah adalah kepala marga, pemerintahan setingkat kecamatan di era sekarang. Proatin atau kerio merupakan kepala dusun/desa. Seorang proatin yang dusunnya berada di ibukota marga, maka dia disebut sebagai pembarap.
"Habis makan masih beberapa lama orang bercakap-cakap di balai. Tetapi lambatlaun seorang-seorang anak pedati mengundurkan diri mencahari tempat merebahkan diri, ada yang oleh karena letih perjalanan sehari-harian dan ada pula oleh karena mengingatkan, bahwa pesirah Karim pasti hendak melepaskan lelah. Akhirnya pesirah Karim pulang ke rumah kecil tempat anak-isterinya, diiringkan oleh pembarap dan peroatin yang menjemput sampai ke lembah Lematang (Alisjahbana, 2010: 102)."

"Telah jauh malam pembarap dan peroatin pun, bermohon mengundurkan diri. Esok dan lusa masih panjang waktu untuk menceritakan segala yang perlu kepada kepala mereka yang baru pulang (Alisjahbana, 2010: 102)."

Ini menjadi bukti betapa pesirah Karim begitu dihormati oleh para bawahannya. Para peroatin dan pembarap menyambut kedatangan pemimpinnya dengan sangat antusias. Mereka mencukupkan seluruh kebutuhan penyambutan pemimpin mereka dengan suka rela dan suka cita. Semua dilakukan dengan tulus dan hormat kepada pemimpinnya.

Dengan penjelasan lain ini bisa dikatakan bahwa setidaknya Pasirah Karim menjalankan, setidaknya, dua jenis kepemimpinan yang mendukung keberhasilan dia menjalankan roda pemerintahan atau kepemimpinannya sebagai seorang pasirah. Hal pertama yang penting adalah kharismatis dan demokratis.

Sebagai pemimpin yang kharismatis, artinya Medasing di dalam masyarakat marga Pasemah dianggap memiliki daya tarik yang bisa memikat orang lain sehingga bersedia menjadi pengikutnya. Pengikutnya tidak mempersoalkan nilai-nilai yang dianut pemimpinnya. Pemimpin seperti ini laksana orang-orang tertentu yang memiliki 'kekuatan ajaib' (Siagian, 2015:37). Secara totalitas, Medaning (atau yang sudah berubah namanya menjadi Pasirah Karim) 
menunjukkan suatu kepribadian yang mampu memancarkan pengaruh dan daya tarik yang teramat besar bagi pengikut atau orang-orang yang dipimpinnya (Kartono, 2014:81).

Sebagai pemimpin yang demokratis yang berorientasi pada manusiamemungkinkan Pasirah Karim untuk bisa memberikan bimbingan dan teladan yang baik dan efektif serta efisien kepada pengikutnya. Ini bisa dilihat dengan efektifnya para pembarap dan peroatin sebagai bawahan di dalam menjalankan roda pemerintahan di dalam marga Pasemah. Hal ini didukung oleh perhatian dan pelibatan Pasirah Karim kepada para peroatin, kerio, dan pembarapnya, juga seluruh rakyatnya di dalam pemerintahan. Hal ini didasari oleh keberadaan seorang pemimpin yang demokratis. Kepemimpinan demokratis adalah pemimpin yang menghargai potensi setiap individu, mau mendengar nasihat dan sugesti dari bawahannya (Kartono, 2014:86). Adanya pelibatan masing-masing potensi yang ada di dalam memajukan wilayah pimpinannya menjadi kunci keberhasilan kepemimpinan Pasirah Karim.

\section{c. Kepemimpinan Agama}

Pada kenyataannya, di dalam bagian fase akhir kehidupannya, Medasing (yang bertransformasi menjadi pesirah Karim) melengkapi status kepemimpinannya untuk menjadi pemimpin agama. Setelah sebelumnya pernah menjadi pemimpin kelompok penyamun dan pemimpin kemasyarakatan, yaitu menjadi seorang pesirah, kini dia juga menjadi pemimpin di bidang keagamaan.

Di masa itu, status sebagai keluarga haji adalah status yang luar biasa, setidaknya status yang di atas rata-rata dibandingkan masyarakat lainnya. Terutama status tersebut bisa dilihat dari sudut keagamaan. Tidak banyak yang sudah bisa melaksanakan rukun Islam kelima tersebut. Hanya orang-orang tertentu yang bisa melaksanakan ibadah haji. Faktor ekonomi menjadi salah satu faktor yang paling menentukan seseorang untuk bisa melaksanakannya.

"Malam itu pertama kali pesirah Karim yang menjadi kepala anak buahnya dalam segala ursan dunia, menjadi pemuka mereka pula berbakti kepada Allah. Pada sembahyang maghrib dan isya orang banyak meminta supaya ia menjadi imam (Alisjahbana, 2010: 102).”

Sebelum naik haji -dua tahun yang lalu- Medasing atau pesirah Karim hanyalah dianggap dan diakui sebagai seorang pesirah, yaitu seorang pemimpin dari suatu kelompok kemasyarakatan. Akan tetapi, setelah menjadi seorang haji, Haji Karim sekaligus dinobatkan menjadi seorang pemimpin di bidang keagamaan. Dia dianggap juga mampu untuk menjadi pemimpin agama. Tugas pertama yang diemban adalah menjadi imam untuk salat maghrib dan isya bagi seluruh warga yang berbahagia atas kembalinya pemimpin kemasyarakatan mereka dan sekaligus pemimpin keagamaan baru mereka.

Kembali kharisma yang kuat dari seorang Pasirah Karim sebagai pemimpin dari suatu kelompok masyarakat semakin meningkat tatkala Pasirah Karim menyempurnakan sisi religi atau keagamaan kehidupannya. Pasirah Karim menjalankan ibadah haji. Ini artinya Pasirah Karim sudah lengkap dan paripurna sebagai umat Islam setelah menjalankan rukun Islam yang kelima, yaitu ibadah haji. Masyarakat yang dipimpinnya semakin yakin dan percaya akan kelebihan dan keunggulan yang dimiliki oleh pemimpin mereka. Dengan menyandang gelar haji masyarakat Pasemah semakin yakin akan sisi keagaam pemimpin mereka. Untuk itu, sebagai simbol (di dalam teks) dinyatakan bahwa Pasirah Karim (yang sekarang sudah mendapat sebutan Haji Karim) mengimami masyarakatnya pada saat penyambutan kepulangan Haji Karim dari tanah suci Mekah (Alisjahbana, 2010: 102).

Ini artinya, selain menjadi pemimpin masyarakat Haji Karim juga juga menjadi pemimpin keagamaan. Haji Karim yang 
dahulunya bernama Medasing menjadi pemimpin di banyak tahapan kehidupannya dan di banyak kondisi kepemimpinan yang diperankannya. Ketika bernama Medasing dia pemimpin kelompok penyamun. Kemudian, ketika berganti nama Karim dia mampu menjadi pemimpin di tingkat marga, yang akhirnya dikenal dengan nama Pasirah Karim. Sedangkan di bagian akhir kehidupannya, dia telah menyempurnakan peran sebagai umat Islam dengan menunaikan ibadah haji. Dari sana dia disebut dengan Haji Karim, dan dia memenuhi perannya sebagai pemimpin agama, dengan disimbolkan mengimami (atau memimpin) ibadah salat.

\section{PENUTUP}

Karya sastra novel Anak Perawan di Sarang Penyamun karya Sutan Takdir Alisjahbana menggambarkan pola-pola kepemimpinan di dalam kelompok atau bidang kehidupan tertentu, di antaranya di kelompok kecil penyamun, di kehidupan sosial kemasyarakatan, dan di ranah keagamaan. Kepemimpinan di kelompok penyamun menggambarkan adanya pola kepemimpinan yang seolah berdasarkan keturunan atau geneologis. Akan tetapi, pola ini ternyata terbantahkan karena sebenarnya Medasing bukanlah anak kandung (atau berdasarkan geneologis) dari pemimpin penyamun sebelumnya. Medasing terpilih menjadi pemimpin kelompok penyamun tersebut karena kelebihan baik fisik maupun supranatural yang dimilikinya. Di dalam kehidupan sosial kemasyarakatannya Medasing yang pada akhirnya insaf dan kembali ke masyarakat biasa juga menjadi pemimpin bagi masyarakatnya dengan jumlah yang jauh lebih banyak. Dia menjadi pesirah, atau pemimpin marga. Di sini pun, seperti halnya kepemimpinan di wilayah uluan lainnya, pesirah dipilih secara demokratis, yaitu dengan suara terbanyak. Biasanya pemilihan tersebut didasarkan oleh pertimbangan atas suatu kelebihan yang dimiliki oleh sosok yang dipilih tersebut.
Sedangkan di bidang keagamaan, Medasing yang akhinya bergelar haji, dan lebih dikenal sebagai pesirah Karim, juga menjadi pemimpin keagamaan yang ada di wilayahnya. Dengan demikian, serasa sempurnalah sudah kehidupan Medasing (atau Pesirah Haji Karim) sebagai manusia.

\section{DAFTAR PUSTAKA}

Alisjahbana, Sutan Takdir. 2010. Anak Perawan di Sarang Penyamun. Jakarta: Dian Rakyat.

Faruk. 2015a. Metode Penelitian Sastra: sebuah Penjelajahan Awal. Yogyakarta: Pustaka Pelajar.

Faruk. 2015b. Pengantar Sosiologi Sastra: dari Strukturalisme Genetik sampai Post-modernisme. Yogyakarta: Pustaka Pelajar.

Kartono, Kartini. 2014. Pemimpin dan Kepemimpinan: Apakah Kepemimpinan Abnormal Itu?. Depok: PT Rajagrafindo Persada.

Departemen Pendidikan Nasional. 2008. Kamus Besar Bahasa Indonesia Edisi Keempat. Jakarta: Gramedia.

Santun, Dedi Irwanto M., Murni, dan Supriyanto. 2010. Iliran dan Uluan: Dikotomi dan Dinamika dalam Sejarah Kultural Palembang. Yogyakarta: Eja Publisher.

Stanton, Robert. 2012. Teori Fiksi. Yogyakarta: Pustaka Pelajar.

Pradopo, Rachmat Djoko. 2011. PrinsipPrinsip Kritik Sastra. Yogyakarta: Gadjah Mada University Press.

Ratna, Nyoman Kutha. 2011. Antropologi Sastra: Peranan Unsur-unsur Kebudayaan dalam Proses Kreatif. Yogyakarta: Pustaka Pelajar.

Ratna, Nyoman Kutha. 2015. Teori, Metode, dan teknik Penelitian Sastra: Dari Strukturalisme hingga Postrukturalisme Perspektif Wacana Naratif. Yogyakarta: Pustaka Pelajar.

Siagian, Sondang P. 2015. Teori dan Praktek Kepemimpinan. Jakarta: PT Rineka Cipta. 
Sudarmanto, Budi Agung. 2012. "Kajian Strukturalisme Genetik Lucien Goldmann dalam Novel Dian yang Tak Kunjung Padam Karya Sutan Takdir Alisjahbana" dalam Jurnal Penelitian Sastra Metasastra Vol. 5, Nomor 2, tahun 2012. Hlm. 107-114. 